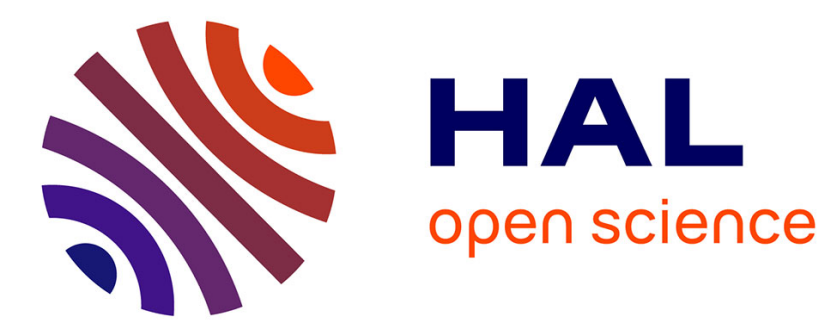

\title{
Should we set-up routine screening for primary sclerosing cholangitis in all IBD patients?
}

Guillaume Bouguen, Miles Peter Sparrow, Xavier Roblin

\section{To cite this version:}

Guillaume Bouguen, Miles Peter Sparrow, Xavier Roblin. Should we set-up routine screening for primary sclerosing cholangitis in all IBD patients?. Digestive and Liver Disease, 2018, 50 (11), pp.11761177. 10.1016/j.dld.2018.07.043 . hal-01903476

\section{HAL Id: hal-01903476 \\ https://hal-univ-rennes1.archives-ouvertes.fr/hal-01903476}

Submitted on 14 Nov 2018

HAL is a multi-disciplinary open access archive for the deposit and dissemination of scientific research documents, whether they are published or not. The documents may come from teaching and research institutions in France or abroad, or from public or private research centers.
L'archive ouverte pluridisciplinaire HAL, est destinée au dépôt et à la diffusion de documents scientifiques de niveau recherche, publiés ou non, émanant des établissements d'enseignement et de recherche français ou étrangers, des laboratoires publics ou privés. 


\section{Should we set-up routine screening for primary sclerosing cholangitis in all IBD patients?}

Guillaume Bouguen ${ }^{1}$, M P Sparrow², Xavier Roblin ${ }^{3}$

1 CHU Rennes, Univ Rennes, INSERM, CIC1414, Institut NUMECAN (Nutrition Metabolisms and Cancer), F-35000 Rennes, France

2_Alfred Hospital and Monash University, Melbourne, Australia

$3 \mathrm{CHU}$ Saint-Etienne, Université de Saint-Etienne, Groupe Immunité des Muqueuses. Agents Pathogènes (GIMAP), F-42000 Saint-Etienne, France

\section{Correspondence to:}

Xavier Roblin

Service de Gastroentérologie et Hépatologie Avenue Albert Raimond, 42270 Saint-Priest-en-Jarez Telephone (0033)- 477828619 Email: xavier.roblin@chu-saint-etienne.Fr

Primary sclerosing cholangitis SC) is an inflammatory stricturing bile duct disease, associated with inflammator boyel case (IBD) in up to $80 \%$ of cases. It is associated with serious hepatobiliary cop (icat narrosis, hepatocellular carcinoma, cholangiocarcinoma) and an increased rof corectal neoplasia, leading ultimately to an increased risk of mortality in patits h. h IBD and PSC. PSC is usually classified as classic (large duct) PSC with successive atation and stricturing of bile ducts, and small duct PSC in cases of normal Magnetic esonance Cholangiography (MRC) with histopathology findings of PSC on liver biop (1-3) In this issue of Digestive and Liver Disease, Belle A. and colleagues report the meriente of the Nancy IBD cohort regarding the prevalence of PSC (4). In this cohort, 233 14 patients underwent MRC and were compared to 187 MRC findings of non-IBD patients. Patients were divided within the IBD group into two groups according to the presence or not of liver function test (LFT) abnormalities. The prevalence of PSC was $9.9 \%$ in the IBD cohort with LFT abnormalities, higher than found in the non-IBD cohort. Only one out of $30(3.3 \%)$ patients without LFT abnormalities was diagnosed with PSC. Biochemically only an increase 
of gamma-glutamyl transferase (GGT) was independently associated with MRC findings of PSC.

Beside the selection bias and the unclear indication for MRC in all patients of the cohort, including controls, this study underlines the high frequency of PSC in IBD patients with abnormal LFT. In a recent Norwegian study, systematic MRC was performed in IBD patients to screen for PSC and $8.1 \%$ of patients (26/322) had associated PSC(5). A recent report at Digestive Disease Week 2018 based on a cohort of patients undergoing systematic Ner biopsy during any IBD surgery detected an even higher PSC prevalence (16.5\%): hro usis histological diagnostic criteria this also included small duct PSC(6). Of note, nean half of these patients had normal LFTs, unlike the Nancy cohort. The natural hign ou comes of small duct PSC without MRC abnormalities remain unclear in the cy ent erature. While liver complications appear to be decreased, whether colorectal cancar n $k$ is dyfferent between the small duct and classic PSC remains to be determined. Giren nown serious natural history outcomes of PSC patients the question of whener a IDS patients should be systematically screened for PSC remains of interest. As undenned by Belle and colleagues, MRC should be performed in all cases of IBD patients vith abnormal LFTs. Whether MRC should be performed in all IBD patients with norm VAs remains questionable, although the results from this study would suggest that th not necessary. In patients with confirmed PSC recommendations for radiological surv illance with MRC, or ultrasound for gallblabber lesions, also remain to be confi ned. rom a luminal viewpoint there is a need to more

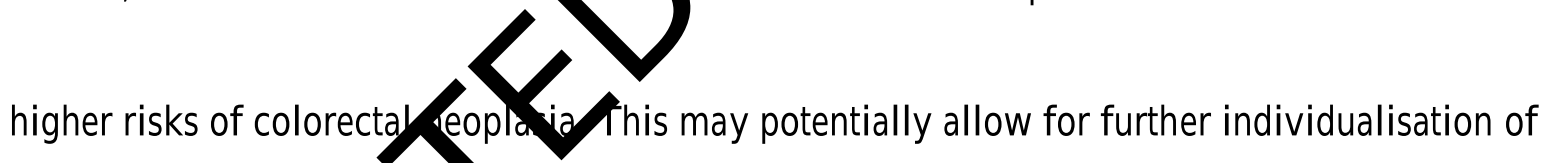
colonoscopic surveiy re remmendations for PSC patients; until such data are produced annual surveillare co noscopies are recommended.

Con icts of Interest: GB received lecture fees from Abbvie, Ferring, MSD, Takeda and Pfize nns onsulting fees from Takeda and Janssen. XR received lecture fees from Abbvie, ens MSD, Takeda, Janssen and Pfizer and consulting fees from Takeda and Janssen. $M S$ has received lecture fees from Janssen, Abbvie, Ferring, Takeda, Pfizer and Shire, comsulting fees from Janssen, Takeda, Pfizer, Celgene, Abbvie and MSD, and research support from Ferring and Orphan. 


\section{REFERENCES}

1 Weismüller TJ, Trivedi PJ, Bergquist A, Patient Age, Sex, and Inflammatory Bowel Disease Phenotype Associate With Course of Primary Sclerosing Cholangitis. 2017;152:1975 84 .

2 Bambha K, Kim WR, Talwalkar J, Incidence, clinical spectrum, an outcomes of primary sclerosing cholangitis in a United States cor unity. 2003;125:1364 9.

3 Fraga M, Fournier N, Safroneeva E, Primary sclerosing angitis in the Swiss Inflammatory Bowel Disease Cohort Study: preval nce, ysk factors, and long-term follow-up.

2017 be9. 7.

4 Belle A, Laurent V, Pouillon et al. Systematic scening for primary sclerosing cholangitis with magnetic resonance cholanoiog vhy-minflammatory bowel disease, dig liv dis

5 Lunder AK, Hov JR, Borthne A Prevalence of Sclerosing Cholangitis Detected by Magnetic Resonance alangiography in Patients With Long-term Inflammatory Bowel Disease. 2016;151:660 9.

6 Miard C, Desfourneau , A ussel-Debry P, et al. Usefulness of Systematic Liver Biopsy During a Sagy 1 flammatory Bowel Disease for the Diagnosis of Primary Scler ing ocongitis Gastroenterology 2018 :154; S20 